ISSN 1991-8631

Original Paper

http://indexmedicus.afro.who.int

\title{
Studies on the efficacy of some preservatives used in packaged orange drinks
}

\author{
Gbonjubola Olusesan ADESHINA* and Josiah Ademola ONAOLAPO \\ Department of Pharmaceutics and Pharmaceutical Microbiology Ahmadu Bello University, Zaria, Nigeria. \\ *Corresponding author; E-mail: dotunkele@yahoo.com ; Tel: +2348037880000
}

\begin{abstract}
The antibacterial activity of benzoic acid and sodium benzoate was investigated against bacterial isolates from packaged orange drinks using agar well diffusion and broth dilution methods. The antibacterial activity of the test agents against the standard NCTC bacteria species was also tested. The bacterial count from the packaged orange drinks ranged from $3.0 \times 10^{5} \mathrm{cfu} / \mathrm{ml}$ and $1.43 \times 10^{6} \mathrm{cfu} / \mathrm{ml}$. The bacteria species detected consisted of Bacillus subtilis, Escherichia coli, Pseudomonas aeruginosa and Micrococcus sp. The zones of inhibition of benzoic acid ranged from $19.0 \mathrm{~mm}-31.5 \mathrm{~mm}$ while that of sodium benzoate ranged from 13.5 $\mathrm{mm}-36.5 \mathrm{~mm}$. The Minimum Inhibitory Concentration (MIC) of the preservatives against the test bacteria ranged between $0.156 \mu \mathrm{g} / \mathrm{ml}$ and $0.625 \mu \mathrm{g} / \mathrm{ml}$ while the Minimum Bactericidal Concentration (MBC) ranged between $0.313 \mu \mathrm{g} / \mathrm{ml}$ and $500 \mu \mathrm{g} / \mathrm{ml}$. The preservatives were more effective against the Gram positive bacteria than the Gram negative bacteria. The preservatives at the concentration used in the examined drinks are inadequate to keep off indicator organisms and to ensure their safe consumption.
\end{abstract}

(c) 2012 International Formulae Group. All rights reserved.

Keywords: Benzoic acid, sodium benzoate, Bacillus subtilis, Escherichia coli, Pseudomonas aeruginosa, Micrococcus sp.

\section{INTRODUCTION}

Antimicrobial preservatives are included in biological preparations to kill or inhibit the growth of microorganisms inadvertently introduced during manufacture or use which may cause microbial deterioration. The use of preservatives in products is to reduce the likelihood of microbial growth in aqueous products and also to minimize the chances of microbial survival in anhydrous products that may be contaminated (Baird, 2004). They are also added to industrial products which may, by their nature, support the growth of bacteria and moulds causing spoilage of the product and possibly infection of the user. Chemical preservatives are frequently used in processed foods to prevent growth of bacteria, yeast or other microorganisms (Jegtvig, 2011). An ideal or satisfactory food preservative remains effective in a product until the product is consumed. Various steps are involved in the processing of orange drink; therefore there is need for preservation.

The commonly used preservatives in packaged orange drinks are benzoic acid and sodium benzoate. Sodium benzoate is a type of preservative commonly used in the fruit pies, jams, beverages, salads, relishes and sauerkraut, typically foods that have an acidic 
pH. Sodium benzoate and water produce benzoic acid, which is the active form of the preservative (Jegtvit, 2011).

Sodium benzoate is utilized in pharmaceutical industry as a diagnostic reagent for liver functions. Sodium benzoate and Benzoic acid are employed in a wide range of preservative applications because of its combination of bactericidal and bacteriostatic action with non-toxicity and tastelessness (Shree additives, 2010).

Benzoic acid would uncouple substrate transport and oxidative phosphorylation from the election transport system by making the cytoplasmic membrane freely permeable to proton (Lou et al., 2007). Benzoates interfere with the utilization of acetate required for the function of energy rich compounds which results in blockage of cell metabolism (Olutimayin et al., 2001). The United States Food and Drug Administration has studied sodium benzoate extensively and found that it is safe when consumed in amounts found in normal diets (Jegtvig, 2011). The $\mathrm{pH}$ value of the products often affects the preservative action of sodium benzoate, the preservative action being much greater at low $\mathrm{pH}$ than at higher $\mathrm{pH}$ values. This study intends to ascertain whether the recommended concentration of the preservatives is able to meet the objectives of its inclusion in the packaged orange drinks.

\section{MATERIALS AND METHODS}

Sample collection

Samples of the packaged orange drinks were purchased from various outlets in Kaduna, Nigeria. The samples were worked on immediately or kept in the refrigerator at 4 ${ }^{0} \mathrm{C}$.

\section{Isolation and identification of bacteria}

Each sample of the packaged orange drinks was diluted between $1: 10$ to $1: 10^{5}$ in sterile normal saline. One milliliter $(1.0 \mathrm{ml})$ of each dilution was added to each McCartney bottle containing the sterile nutrient agar and $3 \%$ Tween 80 and then mixed thoroughly. The content of the bottle was poured into sterile petri dishes and allowed to set. The plates were incubated at $37{ }^{\circ} \mathrm{C}$ for $24-36$ hours. After which the colonies which developed were counted using colony counter. The bacteria isolates were identified using their colonial morphology, cellular morphology and appropriate biochemical tests.

\section{Susceptibility testing}

Exactly $19.0 \mathrm{ml}$ of sterile nutrient agar was inoculated with $0.1 \mathrm{ml}$ of 24-hour broth culture which has been diluted to 0.5 McFarland, which is about $10^{6} \mathrm{cfu} / \mathrm{ml}$. The mixture was properly but gently shaken, poured into sterile petri dishes and allowed to set. A sterile cork borer (No. 4) was used to bore about five equidistant cups into the agar plate. One drop of the molten agar was used to seal the bottom of the bored hole, so that the preservative will not sip beneath the agar. Different concentrations of the preservatives were added to fill the bored holes. One hour pre-diffusion time was allowed, after which the plates were incubated at $37^{\circ} \mathrm{C}$ for 24 hours. The zones of inhibition were then measured in millimeter. Control plates were prepared and incubated appropriately.

\section{Determination of the Minimum Inhibitory Concentration (MIC) and Minimum Bactericidal Concentration (MBC)}

Ten test tubes of $2.5 \mathrm{ml}$ nutrient broth were set in rows. The first tube contained double strength broth. To the first was added $2.5 \mathrm{ml}$ of the preservative and thoroughly but gently mixed, $2.5 \mathrm{ml}$ of the mixture was withdrawn and to the second tube and mixed properly, this dilution continued serially to the last tube, after mixing, $2.5 \mathrm{ml}$ was withdrawn from the last tube and discarded. Each of the tubes was inoculated with $0.1 \mathrm{ml}$ of the standardized inoculum. Three controls were set up to show the sterility of the media, the preservatives and to ascertain the growth promoting property of the media. The tubes were incubated at $37{ }^{\circ} \mathrm{C}$ for 18 hours. The lowest concentration of the preservative in the test tubes that showed no growth was 
considered as the M. I. C. of the preservative against the organisms.

After incubation, a loopful from the tubes containing the least concentration of the preservative which prevent growth was streaked on sterile nutrient agar plates containing inactivating agents $3 \% \mathrm{v} / \mathrm{v}$ Tween 80 and incubated at $37{ }^{\circ} \mathrm{C}$ for 24 hours. The least concentration of the preservative in the test agar plates that showed no growth was considered as the M. B. C. of the preservative against the test organism (Onaolapo et al., 1993).

\section{RESULTS}

The total count of the bacteria from the various orange drinks range from $3.0 \times 10^{5}$ $\mathrm{cfu} / \mathrm{ml}-1.43 \times 10^{6} \mathrm{cfu} / \mathrm{ml}$ (Table 1).The bacterial species isolated from the drinks included pathogens that are officially not permitted in drinks such as Escherichia coli and Pseudomonas aeruginosa. The bacterial load of Micrococcus sp and spore forming Bacillus subtilis isolated from the drinks was also higher than the officially permitted bacterial load for such organisms (Table 1).

From the result of the susceptibility testing, the preservatives showed more antibacterial activity against the Gram positive bacteria than the Gram negative bacteria (Tables 2 and 3). The test bacteria species were more susceptible to the test preservatives than the standard bacteria species except $E$. coli (Tables 2 and 3).

The MIC values of the preservatives were higher against the Gram negative bacteria isolates; E. coli and Ps. aeruginosa, than the Gram positive bacteria isolates; Micrococcus sp. and B. subtilis, which means the preservatives showed more bacteristatic activity against the Gram positive bacteria than the Gram negative bacteria (Figure 1). The MBC values of the benzoic acid against the type bacteria species were relatively higher than those against the bacteria isolates from the drinks, which means that the benzoic acid was more active against the bacteria isolates from the drinks than the type bacteria. However, the MBC values of sodium benzoate against the bacteria isolates from the packaged orange drinks were relatively higher than those against the type NCTC bacteria, that is, sodium benzoate showed more bactericidal activity against type bacteria than bacteria isolates from the drinks (Figure 2).

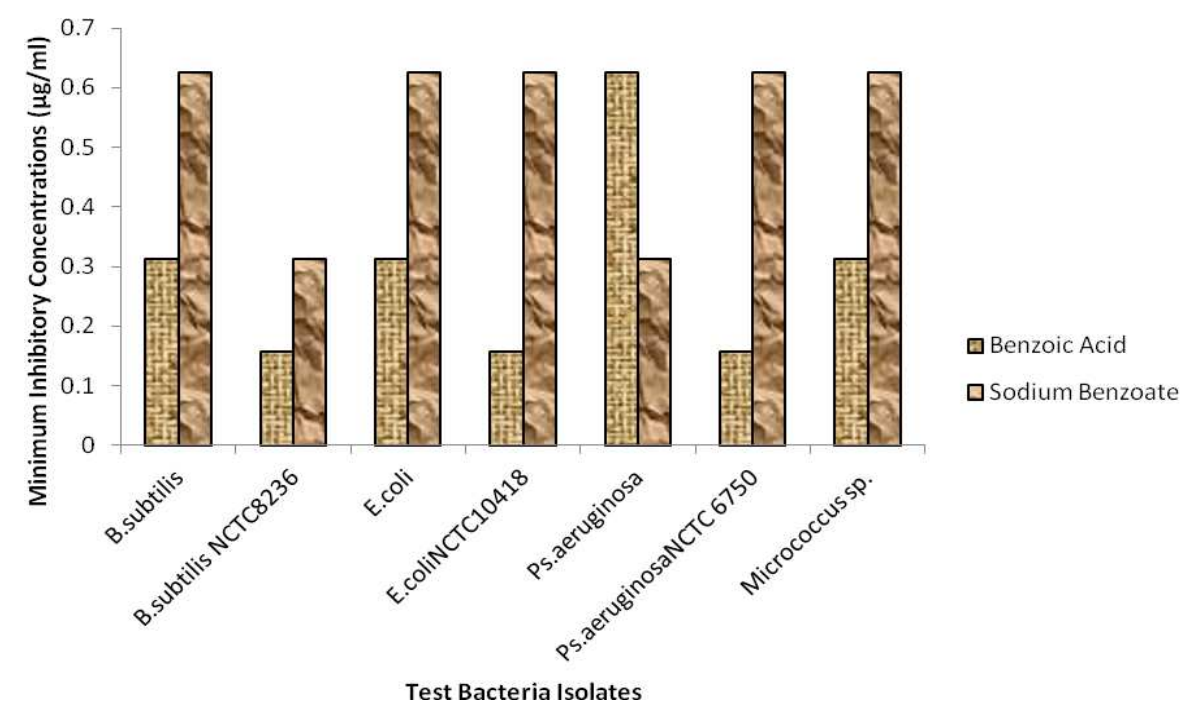

Figure 1: Minimum Inhibitory Concentrations of Benzoic Acid and Sodium Benzoate against the Bacteria Isolates from the Orange Drinks and Type NCTC Bacteria species. 


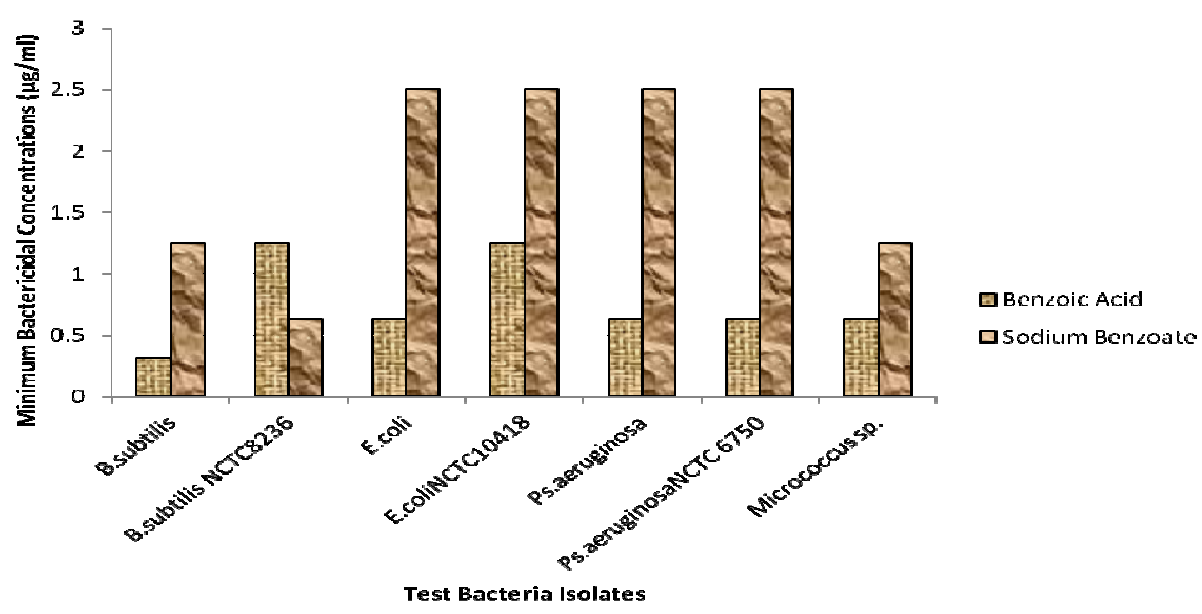

Figure 2: Minimum Bactericidal Concentrations of Benzoic Acid and Sodium Benzoate against the Bacteria Isolates from the Orange Drinks and Type NCTC Bacteria species.

Table 1: Bacterial viable count and distribution of bacteria isolated from the various packaged orange drinks.

\begin{tabular}{ccccccc}
\hline Brand & Sample & $\begin{array}{c}\text { Bacterial viable } \\
\text { count }(\mathbf{c f u} / \mathbf{m l})\end{array}$ & B. subtilis & E. coli & Ps. aeruginosa & $\begin{array}{c}\text { Micrococcus } \\
\text { sp. }\end{array}$ \\
\hline & & & & & + & - \\
$\mathrm{A}$ & 10 & $1.43 \times 0^{6}$ & + & + & + & + \\
$\mathrm{B}$ & 10 & $1.11 \times 10^{6}$ & + & + & + & - \\
$\mathrm{C}$ & 10 & $1.01 \times 10^{6}$ & + & + & - & + \\
$\mathrm{D}$ & 10 & $9.3 \times 10^{5}$ & + & + & - & + \\
$\mathrm{E}$ & 10 & $9.1 \times 10^{5}$ & + & - & - & + \\
F & 10 & $8.1 \times 10^{5}$ & + & - & + & + \\
G & 10 & $3.0 \times 10^{5}$ & + & + &
\end{tabular}

Table 2: Susceptibility of the bacteria isolates from the drinks and type bacteria species to benzoic acid.

\begin{tabular}{lccc}
\hline & \multicolumn{3}{c}{ Zones of Inhibition $(\mathbf{m m})$} \\
\cline { 2 - 4 } Test Bacteria & $\mathbf{0 . 4} \boldsymbol{\mu \mathbf { g } / \mathbf { m l }}$ & $\mathbf{0 . 2} \boldsymbol{\mu \mathbf { g }} / \mathbf{m l}$ & $\mathbf{0 . 1} \boldsymbol{\mu \mathbf { g }} / \mathbf{m l}$ \\
\hline B. subtilis & 31.0 & 29.5 & 28.0 \\
B. subtilis NCTC 8236 & 30.0 & 25.5 & 25.0 \\
E. coli & 27 & 26 & 22 \\
E. coli NCTC 10418 & 31.5 & 31 & 24 \\
Ps. aeruginosa & 24.5 & 22 & 19 \\
Ps.aeruginosa NCTC 6750 & 22 & 21 & 20.5 \\
Micrococcus sp. & 37 & 31 & 28 \\
\hline
\end{tabular}


Table 3: Susceptibility of the bacteria isolates from the drinks and type bacteria species to sodium benzoate.

\begin{tabular}{lccccc}
\hline \multirow{2}{*}{ Test Bacteria } & \multicolumn{5}{c}{ Zones of Inhibition $(\mathbf{m m})$} \\
\cline { 2 - 6 } & $\begin{array}{c}\mathbf{4 . 0} \\
\mathbf{g g} / \mathbf{m l}\end{array}$ & $\begin{array}{c}\mathbf{2 . 0} \\
\boldsymbol{\mu g} / \mathbf{m l}\end{array}$ & $\begin{array}{c}\mathbf{1 . 0} \\
\boldsymbol{\mu g} / \mathbf{m l}\end{array}$ & $\begin{array}{c}\mathbf{0 . 5} \\
\boldsymbol{\mu g} / \mathbf{m l}\end{array}$ & $\begin{array}{c}\mathbf{0 . 2 5} \\
\boldsymbol{\mu g} / \mathbf{m l}\end{array}$ \\
\hline B. subtilis & 36.5 & 34.5 & 31 & 20 & 16.5 \\
B. subtilis NCTC 8236 & 25 & 23 & 17.5 & NI & NI \\
E. coli & 32 & 26 & 15.5 & NI & NI \\
E. coli NCTC 10418 & 27.5 & 17 & NI & NI & NI \\
Ps. aeruginosa & 31.5 & 22.5 & 13.5 & NI & NI \\
Ps. aeruginosa NCTC 6750 & 25 & 19 & NI & NI & NI \\
Micrococcus sp. & 33 & 24.5 & 19 & NI & NI \\
\hline \multicolumn{1}{c}{ NI- No Inhibition } & & & & &
\end{tabular}

\section{DISCUSSION}

The high load of bacteria from the packaged orange drinks, despite the addition of preservatives, suggests low efficiency of the preservatives. The aim of preservation is to satisfactorily keep a product against microbial challenge while it is in trade channel and in analyzed samples. The official limit recommended for microbial contamination of drinking water, which also includes fruit drinks, requires the complete absence of some pathogens like E. coli and other coliforms, Pseudomonas aeruginosa and other organisms like $S$. aureus. Other permissible bacteria should not be more than $10^{3}$ colony forming unit (cfu) $/ \mathrm{ml}$ while mould/yeast should not exceed $10^{2}$ spore forming unit (sfu)/ml (WHO, 2008). Benzoic acid and sodium benzoate had been found to permit the development of some bacteria (Gorman and Scott, 2004). Packaged orange drinks must have a preservative system that is capable of sterilizing the drinks if contamination should occur (Olutimayin et al., 2001).

The result of the test on the efficacy of the preservatives showed that they are more active against Gram positive bacteria, $B$. subtilis and Micrococcus sp than the Gram negative bacteria E. coli and Ps. aeruginosa. Benzoic acid and sodium benzoate have been reported to be less active against Gram negative bacteria (Olutimayin et al., 2001). Gram negative bacteria are known to be resistant to the action of most antimicrobial agents because of the presence of outer phospholipids membrane with the structural lipopolysaccharide components, which make their cell wall impermeable to antimicrobial agents (Willey et al., 2008). Pseudomonas aeruginosa appeared to be less sensitive to the preservatives than all the other organisms. Strains of Pseudomonas sp. have been reported to be less sensitive to many antimicrobial agents (Wiley et al., 2008). Among other factors, the lack of sensitivity to antimicrobial agent by bacteria may be due to inability of the agent to diffuse into the cell and cellular impermeability which leads to a reduced concentration of the antimicrobial compound available at the target site so that the cell may escape injury (Denyer and Russell, 2004).

From the results of the MIC of the preservatives against the organisms, it can be suggested that the recommended concentrations of $0.05 \%-0.1 \%$ is low and may not be active against the isolated bacteria species and this may account for the high bacteria load in the samples. The MIC values showed by sodium benzoate are higher than that of benzoic acid, signifying that benzoic acid is more active than sodium benzoate. Although, benzoic acid was more active against the bacteria isolates from the drinks than the type bacteria. However, the MBC values of sodium benzoate against the bacteria isolates from the packaged orange drinks were relatively higher than those against the type NCTC bacteria, that is, sodium benzoate showed more bactericidal activity against type bacteria than bacteria isolates from the drinks. 
Benzoic acid has limited use in preservatives because it has $\mathrm{pH} 4.2$ which is highly acidic for food products and development of resistance to it by some organisms involving in same cases of metabolism of the acid resulting in complete loss of activity (Gorman and Scott, 2004). This disadvantage is one of the reasons why the salt of benzoic acid, sodium benzoate, is preferred in the preservation of foods and drinks. Therefore, if sodium benzoate is preferred to benzoic acid in preservation, then it is evident from this result that the salt cannot curtail the proliferation of the contaminating bacteria. The result of the MBC of the preservatives against the bacteria sp. also showed that the in-use concentration of sodium benzoate is low if the orange drinks are to remain safe for consumption. When used as a preservative, sodium benzoate is typically added to foods in small amounts only. If too much is added, food may take on a very bitter taste (EllisChristensen, 2011).

\section{Conclusion}

Generally, the susceptibility of the bacteria isolates and standard NCTC bacteria to the tested preservatives was relatively good in-vitro; the used preservatives were not able to curtail the proliferation of bacteria in the tested packaged orange drinks in-vivo. It is therefore suggested that due to the fact that the preservatives at high concentration may have adverse effect on the drinks and on the consumers, the use of other preservatives of local sources can be considered for the preservation of the packaged drinks.

\section{REFERENCES}

Baird RM. 2004. Microbial spoilage, infection risk and contamination control. In Hugo and Russell's Pharmaceutical Microbiology $\quad\left(7^{\text {th }}\right.$ edn $), \quad$ Stephen, Norman, Sean (eds). Blackwell Scientific Publications: Oxford; 263283.

Denyer SP, Russell AD. 2004. Non-antibiotic antibacterial agents: Mode of action and resistance. In Hugo and Russell's
Pharmaceutical Microbiology ( $7^{\text {th }}$ edn), Stephen, Norman, Sean (eds). Blackwell Scientific Publications: Oxford.

Gorman S, Scott Es. 2004. Chemical disinfectants, antiseptics and preservatives. In Hugo and Russell's Pharmaceutical Microbiology $\left(7^{\text {th }}\right.$ edn) Stephen, Norman, Sean (eds). Blackwell Scientific Publications: Oxford; 285305.

Jegtvig S. 2011. Sodium benzoate. About.com Nutrition. Updated 17June2011. Available at: http://www.nutrition. about.com/od/changeyourdiet/a.sodiumb enzoate.htm.

Lou P, Hansen BS, Olsen PH, Tullin S, Murphy MP, Brand MD. 2007. Mitochondrial uncouplers with an extraordinary dynamic range. Biochem. J., 401(1): 129-140.

Olutimayin GO, Onaolapo JA, Ibrahim K. 2001. The Surface Charge of the Bacterial Isolates from Orange Drinks. Nigerian J. Biotechnol., 12(1): 74-81.

Onaolapo JA. 1993. Preliminary study on the antimicrobial activities of Cassia tora and Cassia occidentalis. Glimpses Plant Res., 11: 533-536.

Shree Additives. 2010. Sodium Benzoate and Benzoic acid I.P. [cited 29 Aug 2011]. Available at: http://www.shreeadditives. com/htmlsite/5f.htm

Ellis-Christensen T. 2011: What is Sodium Benzoate? In Hugo and Russell's Pharmaceutical Microbiology ( $7^{\text {th }}$ edn), Stephen, Norman, Sean (eds). Blackwell Scientific Publications: Oxford; 306321.

Willey JM, Sherwood LM, Woolverton CJ. 2008. Prescott, Harley and Klein's Microbiology $\quad\left(7^{\text {th }}\right.$ edn). McGrawHill Company: America; 578.

WHO. 2008. Guidelines for drinking-water quality. Third edition incorporating the first and the second addenda. World Health Organization: Geneva. 